\title{
A role for age-related changes in TGF $\beta$ signaling in aberrant chondrocyte differentiation and osteoarthritis
}

\author{
Peter M van der Kraan*, Esmeralda N Blaney Davidson and Wim B van den Berg
}

\begin{abstract}
Transforming growth factor beta (TGF $\beta$ ) is a growth factor with many faces. In our osteoarthritis (OA) research we have found that TGF $\beta$ can be protective as well as deleterious for articular cartilage. We postulate that the dual effects of TGF $\beta$ on chondrocytes can be explained by the fact that TGF $\beta$ can signal via different receptors and related Smad signaling routes. On chondrocytes, TGF $\beta$ not only signals via the canonical type I receptor ALK5 but also via the ALK1 receptor. Notably, signaling via ALK5 (Smad2/3 route) results in markedly different chondrocyte responses than ALK1 signaling (Smad1/5/8), and we postulate that the balance between ALK5 and ALK1 expression on chondrocytes will determine the overall effect of TGF $\beta$ on these cells. Importantly, signaling via ALK1, but not ALK5, stimulates MMP-13 expression by chondrocytes. In cartilage of ageing mice and in experimental $\mathrm{OA}$ models we have found that the ALK1/ALK5 ratio is significantly increased, favoring TGF $\beta$ signaling via the Smad1/5/8 route, changes in chondrocyte differentiation and MMP-13 expression. Moreover, human OA cartilage showed a significant correlation between ALK1 and MMP-13 expression. In this paper we summarize concepts in $\mathrm{OA}$, its link with ageing and disturbed growth factor responses, and a potential role of TGF $\beta$ signaling in OA development.
\end{abstract}

\section{Introduction}

Osteoarthritis $(\mathrm{OA})$ is the joint disease with the highest incidence. The disease is in general divided into primary $\mathrm{OA}$ and secondary OA. Primary OA has no obvious

\footnotetext{
*Correspondence: P.vanderkraan@reuma.umcn.nl
}

Experimental Rheumatology \& Advanced Therapeutics, NCMLS, Radboud University, Medical Centre Nijmegen, Geert Grooteplein 28, 6525 GA Nijmegen, the Netherlands trigger, while secondary OA is the result of an evident underlying affliction. The main features of this disease are cartilage erosion, synovial fibrosis, osteophyte formation at the joint margins and sclerosis of the subchondral bone. Patients with OA suffer from joint pain and tenderness, occasional effusions and, in the long run, loss of joint function.

The etiology of primary OA is not known but several risk factors have been detected. Systemic risk factors include genetic background, ethnicity, gender and obesity, but the main risk factor for the initiation and progression of primary OA is ageing. Functional articular cartilage is maintained by the cartilage cells, chondrocytes. Changes in chondrocytes, leading to the inability of these cells to maintain the homeostasis of articular cartilage, can be expected to be at the root of OA development. In view of the fact that the principal risk factor of OA is ageing, agerelated changes in chondrocytes are likely to be involved in OA development.

\section{Changes in osteoarthritic chondrocytes}

Cartilage is, on a weight basis, mainly composed of collagens and proteoglycans. Collagens - for the most part type II, type IX and type XI - provide tensile strength, while the proteoglycan aggrecan retains water in the matrix. In humans, cartilage is composed of three zones: superficial zone, middle zone and deep zone. The superficial zone contains disc-shaped chondrocytes, the cells in the middle zone cells are more spherical and the deep zone contains spherical chondrocytes arranged in columns.

Cartilage damage in OA has several characteristics. At the initial stages of OA the cartilage surface is intact but focal edema and minor fibrillations can be observed. Subsequently the superficial zone becomes fibrillated and chondrocytes are lost from this zone. Finally, fibrillations progress into fissures - a process that is followed by cartilage erosion, denudation of bone and joint deformation.

At the initial stages of $\mathrm{OA}$, chondrocytes start to multiply and form multicellular clusters. In addition, chondrocytes expressing markers of hypertrophic 
chondrocytes are found in OA cartilage. A subpopulation of OA chondrocytes synthesizes molecules that, under normal conditions, are only expressed by terminally differentiated (hypertrophic) chondrocytes, normally found in growth plates. Expression of osteocalcin, alkaline phosphatase, c-maf, Runx2 and type $\mathrm{X}$ collagen has been demonstrated in OA chondrocytes [1-5]. Moreover, chondrocytes in OA cartilage express high levels of matrix metalloproteinase 13 (MMP-13), the enzyme most potently degrading type II collagen [6]. This underscores the hypertrophy-like character of OA chondrocytes since MMP-13 is highly upregulated during chondrocyte terminal differentiation, and deficiency of MMP-13 even results in impaired endochondral ossification $[7,8]$.

During OA, cartilage matrix degradation exceeds matrix deposition resulting in net matrix loss. In contrast to what is observed in inflammatory arthritis, mRNA expression and synthesis of a number of matrix molecules is increased instead of decreased compared with normal cartilage $[9,10]$. Only in the very late stages of OA does synthesis of matrix molecules drop below control levels. The synthesis of the main structural component of cartilage, type II collagen, is clearly enhanced in OA cartilage $[11,12]$. In OA cartilage, both catabolism (for example, MMP-13 synthesis) and anabolism (type II collagen synthesis) are high. It is unclear whether elevated catabolism and enhanced anabolism is achieved by the same cells or by different chondrocyte subpopulations.

\section{Catabolic cytokines}

Catabolic cytokines have been suggested to play a dominant role in OA. Chondrocytes can be stimulated by catabolic cytokines to release cartilage degradation products, ultimately leading to damage. A cytokine that is suggested to be a principle mediator of joint damage in OA is IL-1. Chondrocytes from OA cartilage display high levels of IL- $1 \alpha$ and IL-1 $\beta$ and have elevated expression of the plasma membrane-bound IL-1 receptor I, while the decoy IL-1 receptor II is downregulated in OA chondrocytes [13]. Not only do fibrillated areas show these expression patterns, but also cartilage proximal to macroscopic OA lesions demonstrates a higher binding of TNF $\alpha$ and IL-1 $\beta$ compared with chondrocytes from morphologically normal cartilage in the same joint [14]. This indicates not only that the levels of IL-1 are increased in OA joints, but also that OA chondrocytes are more sensitive to IL-1.

IL-1 is considered a principle mediator of joint damage in OA. IL-1 has the ability to stimulate chondrocytes to degrade both aggrecan and collagen [15]. This cytokine causes destruction of cartilage by increasing enzyme activity while decreasing the synthesis of enzyme inhibitors [16]. IL-1 can stimulate chondrocytes to produce nitric oxide [17], matrix metalloproteinases [18] and aggrecanases
(ADAMTS) [19], and suppresses the synthesis of aggrecan and collagen type II [20-22].

The latter is remarkable if IL-1 plays a dominant role in OA pathophysiology. IL-1 is a potent inhibitor of chondrocyte type II collagen synthesis, but type II collagen synthesis is increased during OA as discussed above. This discrepancy points to alternative players that are involved in OA. IL-1 might play a role in the induction of enzyme expression but is unlikely to be the only factor that determines development and progression of OA.

Osteoarthritic chondrocytes also express, besides catabolic factors, anabolic factors such as transforming growth factor beta (TGF $\beta$ ) [23,24]. Increased synthetic activity in early OA has been found to be accompanied with an upregulation of TGF $\beta$ expression $[25,26]$. We propose a role for TGF $\beta$ not only as a cartilage protective agent but also as a mediator of cartilage degeneration during ageing and OA development.

\section{Transforming growth factor beta}

The TGF $\beta$ superfamily is composed of over 35 members. The family members play fundamental roles in development and homeostasis. In mammals, three isotypes of TGF $\beta$ are found: $\beta_{1}, \beta_{2}$ and $\beta_{3}$. Expression of these three isoforms is differently regulated at the transcriptional level due to dissimilar promoter sequences [27].

TGF $\beta$ is secreted as an inactive complex and requires activation before it is able to bind to its receptor [28]. Activated TGF $\beta$ binds to the TGF $\beta$ type II receptor and forms a complex that recruits the TGF $\beta$ type I receptor, ALK5. TGF $\beta$ has also recently been shown, however, to have the ability to signal via the alternative TGF $\beta$ type I receptor ALK1 in chondrocytes. In endothelial cells, but also in chondrocytes, activation of the ALK5 route is followed by Smad2 or Smad3 phosphorylation while ALK1 has been found to result in phosphorylation of Smad1, Smad5, or Smad8 [29-31]. The activated receptor Smads form a complex with the co-Smad, Smad4 - this complex translocates to the nucleus and modifies gene expression. Interestingly, signaling via either ALK5 or ALK1 can determine the response of cells to TGF $\beta$ stimulation, which can be totally contrary $[32,33]$. For example, in endothelial cells ALK5 inhibits migration whereas ALK1 stimulates migration and proliferation [34].

Signaling via the Smad pathway appears to be the most important signaling pathway for TGF $\beta$, but this is not the only pathway. Mitogen-activated protein kinase, Rho-like GTPase and phopshatidylinositol-3-kinase pathways are involved in TGF $\beta$ signaling (reviewed in [35]). Activation of TGF $\beta$ activated kinase 1 occurs independent of ALK5 kinase activity and results in P38 and JNK signaling [36]. That TGF $\beta$ activates different pathways calls attention to the fact that one has to take into account the differences 
in management of the TGF $\beta$ signal in different cell types and the subsequent variation in TGF $\beta$ effects.

Transforming growth factor beta and osteoarthritis Family studies have indicated a relation between TGF $\beta$ and a disease related to OA. In Japanese women a polymorphism of TGF $\beta_{1}$ on position 29 ( $\mathrm{T}$ to $\mathrm{C}$, amino acid 10) positioned in the signal sequence region of TGF $\beta_{1}$ is related to an elevated prevalence of spinal osteophytosis and ossification of the posterior longitudinal ligament $[37,38]$.

Asporin inhibits TGF $\beta$-mediated expression of cartilage matrix genes such as collagen type II and aggrecan, and inhibits accumulation of proteoglycan [39]. Kizawa and colleagues found an asporin polymorphism that showed a significantly higher frequency in OA [39]. The D-14 polymorphism had a stronger inhibitory effect on TGF $\beta$ than the common D-13 repeat. This indicates that expression of D-14 results in strong TGF $\beta$ inhibition and that this is associated with OA development. When this study was repeated in a Spanish Caucasian population by Rodriguez-Lopez and colleagues, however, the higher susceptibility to OA of people with the D-14 polymorphism was not found [40]. In a subset of UK Caucasians, a trend was seen towards a higher degree of D-14 polymorphism in OA. In a different ethnic group of Asian origin, Han Chinese, the OA susceptibility was again found [41]. These studies indicate that reduced TGF $\beta$ signaling can result in OA development.

Mice deficient for Smad3 developed degenerative joint disease resembling human OA. Chondrocytes present in the articular cartilage of Smad3-deficient mice showed enhanced chondrocyte hypertrophy indicated by increased expression of type $\mathrm{X}$ collagen. These data indicate that Smad3 signaling is essential for repressing chondrocyte terminal differentiation. This observation is supported by studies in mice that overexpress a dominant-negative TGF $\beta$ type II receptor in skeletal tissues [42]. These mice developed progressive skeletal degeneration that strongly resembles human OA. In addition, mice that lack latent TGF $\beta$ binding protein 3 also show altered chondrocyte differentiation and early OA development [43,44]. Interference with normal TGF $\beta$ signaling apparently results in aberrations in chondrocyte differentiation and enhanced OA development.

The effects of TGF $\beta$ on chondrocytes seem to be context related. Serum factors can modulate the effect of TGF $\beta$ on chondrocyte proliferation. Growth of cultured rabbit chondrocytes decreased after TGF $\beta$ stimulation in the presence of a low serum concentration, while the cell number increased in the presence of high serum levels $[45,46]$. The rabbit chondrocytes demonstrated differences in TGF $\beta$ receptor expression as a function of cell cycle progression [47-49]. Moreover, expression of TGF $\beta$ receptors appeared to be changed by nitric oxide and
ROS levels and OA chondrocytes became insensitive to TGF $\beta$, which was concomitant with loss of the expression of TGF $\beta$ type II receptor on these chondrocytes [50,51]. A loss of the TGF $\beta$ type II receptor has also been observed by our own group during ageing and $\mathrm{OA}$ in murine models [52,53]. Moreover, proteoglycan synthesis is also differentially regulated by TGF $\beta$ in rabbit and bovine chondrocytes depending on the differentiation stage of the chondrocytes [54,55]. In calf cartilage explants, proteoglycan synthesis is stimulated by TGF $\beta$ in a dose-dependent manner [56,57]. From these observations it can be concluded that, in general, TGF $\beta$ maintains chondrocyte and cartilage homeostasis but that changes in differentiation stage and associated alterations in receptor expression modify the effect of TGF $\beta$ on chondrocyte function.

We have shown in young mice that TGF $\beta$ has favorable effects on cartilage, such as stimulation of proteoglycan synthesis in cartilage [58]. In old mice, however, stimulation of aggrecan synthesis by TGF $\beta$ is reduced - and this is associated with a loss in ALK5 expression, and TGF $\beta$ type II receptor expression, on articular chondrocytes [59]. Livne and colleagues showed in mandibular chondrocytes a strong age-related decrease in stimulation of proteoglycan synthesis by TGF $\beta$ in young mice (1 month old, $+120 \%$ ) and old mice (18 months old, $+7 \%$ ) $[59,60]$. Nonchondrocytic cells have also been shown to display a diminished response to TGF $\beta$ during ageing. Smooth muscle cells derived from old rats produce normal levels of TGF $\beta$ but fail to respond to the inhibitory effects of this growth factor in contrast to young cells [61]. The response to TGF $\beta$ appears to be age related and a change in TGF $\beta$ signaling can play a role in age-related diseases such as OA.

\section{Control of chondrocyte differentiation by SMADs}

Activation of the Smad1/5/8 route in chondrocytes is strongly associated with chondrocyte terminal differentiation and hypertrophy [62]. Bone morphogenetic protein itself or activation of the bone morphogenetic protein pathway $(\operatorname{Smad} 1 / 5 / 8)$ leads, both in the growth plate and in articular chondrocytes, to expression of terminal differentiation markers [63-65]. Signaling via Smad1 cooperates with the transcription factor Runx2 (CBFA1) to induce chondrocyte terminal differentiation. This cross-talk between the bone morphogenetic proteinassociated Smads and Runx2 is essential to stimulate the expression of hypertrophy markers in differentiating chondrocytes [66]. Blocking the Smad1/5/8 route by overexpression of Smad6 reduced the expression of both type $\mathrm{X}$ collagen and alkaline phosphatase activity in chondrocytes, while using Smad6 antisense had an opposite effect [67]. Moreover, in vivo inhibition of Smad1/5/8 phosphorylation, as observed in Smad6 
transgenic mice, was associated with delayed chondrocyte hypertrophy [68]. In articular chondrocytes treated with azacytidine, reduced Smad2 and Smad3 expression and signaling and increased Smad1/5 expression correlated with elevated synthesis of type X collagen and alkaline phosphatase. These observations clearly demonstrate that terminal differentiation of articular chondrocytes is associated with dominant signaling via the Smad1/5/8 pathway [69].

The latter observation shows not only that activation of the $S \operatorname{mad} 1 / 5 / 8$ route leads to terminal differentiation but also that loss of $S \operatorname{mad} 2 / 3$ can lead to induction of chondrocyte terminal differentiation. The inhibitory effects of TGF $\beta$ on chondrocyte maturation is mediated by the $\operatorname{Smad} 2 / 3$ pathway, as has been shown by overexpression of dominant negative Smad2 and Smad3 in chondrocytes. Mutant mice deficient for functional Smad3 show abnormally increased numbers of type $\mathrm{X}$ collagen-expressing chondrocytes in articular cartilage. Overexpression of both Smad2 and Smad3 blocked spontaneous maturation in Smad3-deficient chondrocytes $[70,71]$. Smad2 and Smad3 are key mediators of the inhibitory effect of TGF $\beta$ on chondrocyte terminal differentiation [72]. Without Smad2/3 signaling, chondrocytes break their quiescent state and undergo anomalous terminal differentiation. Apparently the balance between Smad1/5/8 signaling and Smad2/3 signaling controls chondrocyte differentiation.

The wnt signaling pathways are involved in chondrocyte differentiation and OA development [73]. Enhanced and decreased wnt signaling both result in cartilage loss $[74,75]$. Furthermore, the wnt inhibitor dickkopf1 stimulated chondrocyte apoptosis in OA joints [76]. Increased wnt signaling can have a direct effect on chondrocyte differentiation but it can also alter differentiation by variable modulation of the $\operatorname{Smad} 2 / 3$ and $S \operatorname{mad} 1 / 5 / 8$ pathways. wnt signaling leads to inhibition of the activity of the GSK3 kinase, which resulted in Xenopus embryos in prolonged duration of the Smad1 signal [77]. If a similar mechanism takes place in chondrocytes, enhanced wnt signaling will result in augmented terminal differentiation.

Chondrocyte differentiation is regulated by Sox9, and additional Sox molecules, but chondrocyte terminal differentiation is rigorously controlled by the transcription factor Runx2 [78,79]. Mice lacking Runx2 do not show chondrocyte terminal differentiation, and bone formation via this pathway is totally blocked [80]. Smad pathways are integrated via Runx 2 to control chondrocyte terminal differentiation. Interaction of Runx2 with Smad1 facilitates the function of Runx2 in stimulating terminal differentiation, while Smad3 blocks Runx2 function [81-83]. The Smad2/3 and Smad1/5/8 balance controls the Runx2 function and terminal differentiation.

\section{Change in transforming growth factor beta signaling in ageing chondrocytes and osteoarthritis}

We have demonstrated an age-related loss of TGF $\beta$ type I receptor ALK5 and phosphorylation of Smad2/3 in murine articular cartilage [84]. Expression of nonphosphorylated Smad2 was not altered during ageing. Moreover, in two experimental models of OA - the DMM (meniscus destabilization) model and STR/ORT mice (spontaneous OA) - development of the disease was correlated with a loss of ALK5 expression. Expression of the alternative TGF $\beta$ receptor, ALK1, did not decrease to a similar extent as ALK5 [85]. As a result, the ratio of ALK1/ALK5 expressing cells strongly increased in OA articular chondrocytes. During ageing of $\mathrm{C} 57 \mathrm{Bl}$ mice, the ratio ALK1/ALK5 increased up to sixfold. In the DMM model, OA develops on the medial tibial side while the lateral side is relatively protected. A more than threefold increase in the ALK1/ALK5 ratio was observed on the medial side while the ratio on the lateral side was unaffected. STR/ORT mice develop OA starting at the medial tibia from an age of 2 to 3 months. The ALK1/ ALK5 ratio was 5 on the medial tibia at an age of 3 months and was 18 in 1-year-old animals. The lateral tibia showed a ratio increase from 1 to 5 in the same period. Clearly an increased ALK1/ALK5 ratio in chondrocytes is associated with ageing and $\mathrm{OA}$ development [85].

We postulate that the loss of ALK5 expression and the concomitant elevated ratio of ALK1/ALK5 will have profound effects on chondrocyte behavior. The effect of TGF $\beta$ on chondrocytes will be governed by the ALK1/ ALK5 ratio. A prevailing expression of ALK5 will result in a dominance of the $S \operatorname{mad} 2 / 3$ signaling route, while ALK1 dominance will result in a stronger Smad1/5/8 pathway. The balance of these routes has been shown to control chondrocyte differentiation (see above).

We and others have shown that TGF $\beta$ signals in chondrocytes not only via ALK5 but also via ALK1 [86]. Exposure of chondrocytes to TGF $\beta$ results in both Smad2/3 and Smad1/5/8 phosphorylation within 15 to 30 minutes [85]. In addition, overexpression of constitutive active ALK5 (Smad2/3) results in increased expression of aggrecan while constitutive ALK1 (Smad1/5/8) expression leads to elevated expression of MMP-13. Blocking ALK5 expression using siRNA resulted in elevated expression of MMP-13 [85]. The ALK1 (Smad1/5/8) and ALK5 (Smad3) signaling balance in chondrocytes apparently determines MMP-13 expression. In addition, a clear trend towards elevated type II collagen and aggrecan expression was observed in cells with constitutive active ALK1. Noticeably, human osteoarthritic cartilage demonstrated a significant correlation between ALK1 and MMP-13 mRNA expression and a trend $(P=0.05$ to 0.1$)$ with type II collagen and aggrecan 


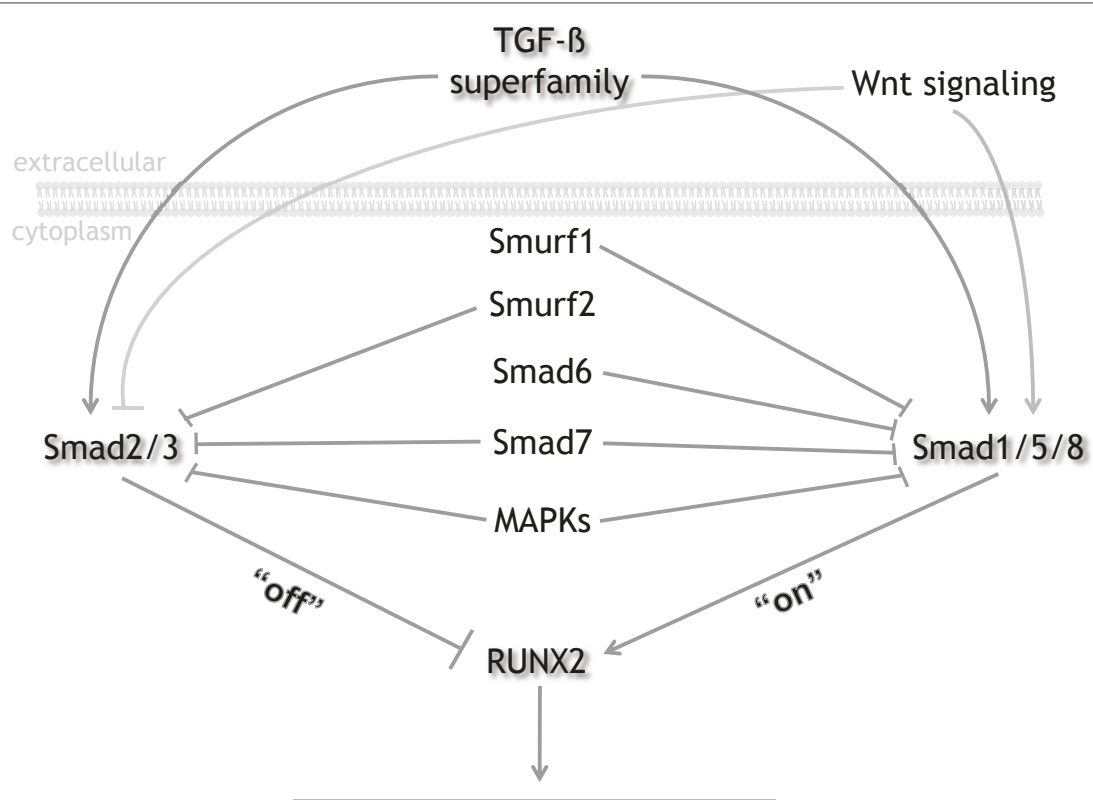

"terminal differentiation"

Figure 1. Alterations in transforming growth factor beta signaling cause changes in chondrocyte differentiation and osteoarthritis development. Transforming growth factor beta (TGF $\beta$ ) can either signal by the Smad2/3 route (canonical) or the Smad1/5/8 route. Smad2/3 and Smad1/5/8 form a complex with Smad4 that enters the nucleus and modulates gene expression and Runx 2 function. The signaling by Smad2/3 and Smad1/5/8 is differentially modified by a number of intracellular molecules. Both Smad routes are blocked by Smad7, while Smad6 blocks preferentially the Smad1/5/8 pathway $[100,101]$. wnt signaling modifies these pathways by stabilization of Smad1/5/8 [102]. Smurf1 and Smurf2 are E3 ubiquitin ligases that inhibit Smad signaling. Smurf1 triggers the degradation of Smad1/5/8 while Smurf2 stimulates mainly the degradation of Smad2/3 [103]. Mitogen-activated protein kinases (MAPKs) modulate the stability and degradation of the Smads by phosphorylation of these molecules [102].

expression. These observations indicate that ALK1 signaling can induce a chondrocyte phenotype similar to that found in OA cartilage, a phenotype with simultaneous enhanced expression of matrix molecules and MMP-13.

We hypothesize that articular chondrocytes reside in a quiescent state in young healthy cartilage due to the inhibitory effect of TGF $\beta$, via Smad2/3, on the progression of chondrocyte differentiation. During ageing of chondrocytes and OA development, signaling through ALK1 and Smad1/5/8 is increased in favor of signaling via ALK5 and Smad2/3. The dominant Smad1/5/8 signaling triggers the articular chondrocytes to leave their quiescent state (Figure 1). This leads to a chondrocyte phenotype with characteristics analogous to terminal differentiated growth plate chondrocytes - a chondrocyte with an autolytic phenotype typified by degradation of its surrounding cartilage matrix, as can be found in OA cartilage.

This hypothesis can explain the often enigmatic effects of TGF $\beta$ on articular cartilage. The effect of TGF $\beta$ on chondrocytes will be determined by the relative expression of ALK5 and ALK1. In general, we have observed in young animals that TGF $\beta$ is protective for articular cartilage [84,87-90]. Prolonged exposure of cartilage to high TGF $\beta$ levels, however, induces osteoarthritic lesions in murine knee joints, starting in the deep zones [91]. We have observed that the chondrocytes in the deep zone, just above the tidemark, show high ALK1 expression (personal observation). In old animals, showing a decrease in the ALK5/ALK1 ratio, the protective effect of TGF $\beta$ is lost and TGF $\beta$ can act as an OA-inducing factor $[85,92,93]$ (Table 1$)$.

In conclusion, loss of the $\operatorname{Smad} 2 / 3$ signaling and relatively enhanced Smad1/5/8 signaling can explain the enigmatic observation in OA cartilage of elevated expression of both matrix molecules and proteolytic enzymes, like MMP-13. Moreover, the age-related loss of ALK5 signaling in chondrocytes can give a clue to the high correlation between ageing and OA development. Interestingly, a remarkable relationship has been reported between reduced TGF $\beta$ signaling and another, highly agerelated affliction, Alzheimer's disease [94,95]. Alzheimer's disease is characterized by progressive neurodegeneration and cerebral accumulation of the $\beta$-amyloid peptide. Reduced TGF $\beta$ type II receptor expression and signaling has been demonstrated in Alzheimer's disease. Overexpression of dominant negative Smad3 causes neurodegeneration in cell cultures, indicating that loss of 

(type II collagen) and increased MMP-13 production

MMP-13, matrix metalloproteinase 13; TGF $\beta$, transforming growth factor beta.

Smad2/3 signaling is involved. Reducing neuronal TGF $\beta$ signaling via the Smad2/3 pathway in mice resulted in agedependent neurodegeneration. These findings show that reduced TGF $\beta$ Smad3-dependent signaling in neuronal cells increases age-dependent neurodegeneration and Alzheimer's disease-like symptoms. This observation points to a striking similarity between authentic Alzheimer's disease and Alzheimer's disease of the joint - OA.

\section{Targets for therapy}

We postulate that the OA process is driven by the loss of the Smad2/3 block on differentiation in articular chondrocytes, leading to progression of chondrocyte differentiation and an autolytic phenotype. In the early stages of OA - bearing in mind that OA is initially a focal process - not all chondrocytes will be at the same stage of differentiation. A mixture of cell populations will be present in OA cartilage. Some chondrocytes will have progressed in their differentiation to an OA chondrocyte phenotype, triggered by a loss of the Smad2/3 block. Other cells will still be in a quiescent, healthy state of differentiation. The latter cells can be targets for therapy to block further progression of the OA process. Blocking the progression of chondrocyte differentiation will block further expansion of the OA process in remaining healthy cartilage.

Loss of Smad $2 / 3$ signaling is at the root of the OA process in our view. To inhibit articular chondrocytes in their deviant differentiation, this pathway has to be stimulated at the same time as circumventing the role of the ALK1 receptor. Compounds specifically stimulating the Smad2/3 route should be developed. A similar strategy, using TGF $\beta$ mimetics, has been proposed to treat Alzheimer's disease [96]. TGF $\beta$ mimetics have already been developed that can mimic TGF $\beta$ effects on cells [97].

An alternative therapy could be stimulation of one of the other Smad2/3 routes in chondrocytes. Signaling via the activin ALK4 and ALK7 receptors leads to activation of the Smad2/3 pathway [98]. Little is known about the expression of these receptors in old chondrocytes, but potentially these receptors could be targets to enhance Smad2/3 signaling in chondrocytes in OA.

An alternative strategy would be blocking ALK1 or the Smad1/5/8 pathway in chondrocytes to block the trigger that stimulates progression of chondrocyte differentiation. Since ALK1 is involved in vessel formation, blocking ALK1 can interfere with this process [99]. As blockers of ALK1 to treat OA will be mainly applied in middle-aged and older people, additional effects of this treatment are expected to be limited. General blocking of the Smad1/5/8 pathway using kinase blockers that inhibit the activity of ALK1, ALK2, ALK3 and ALK6 is an alternative option to stop chondrocyte aberrant differentiation.

The potential side effects of the above therapies are unclear. Effects on growth plate chondrocytes will be absent since the growth plates are not present in elderly humans. The effects of stimulating the Smad2/3 pathway using TGF $\beta$ mimetics or the ALK4/7 pathway could result in side effects, such as induction of fibrosis. Blocking ALK1 will have few side effects due to the restricted effect of ALK1 in vessel formation, which is anticipated to be relatively unimportant in elderly people. The effects of general inhibition of the Smad1/5/8 pathway in elderly people are hard to predict but this might interfere with bone metabolism. Bone morphogenetic protein signaling is known to be involved in both bone formation and bone degradation, the latter by stimulation of osteoclast maturation. 


\section{Conclusion}

Until now no effective therapy has been developed for OA that interferes with disease progression. Painkilling and joint replacement are the only options at this moment. The proposed treatment attacks the OA process at its core, blocking the generation of chondrocytes with an autolytic phenotype. The proposed OA mechanism and potential therapies open the venue to new strategies to treat this common crippling joint disease.

\section{Abbreviations}

$\mathrm{IL}$ = interleukin; MMP-13 = matrix metalloproteinase 13; OA = osteoarthritis; TGF $\beta=$ transforming growth factor beta; TNF = tumor necrosis factor.

\section{Competing interests}

The authors declare that they have no competing interests.

Published: 29 January 2010

\section{References}

1. Pullig O, Weseloh G, Ronneberger D, Kakonen S, Swoboda B: Chondrocyte differentiation in human osteoarthritis: expression of osteocalcin in normal and osteoarthritic cartilage and bone. Calcif Tissue Int 2000, 67:230-240.

2. Kirsch T, Swoboda B, Nah H: Activation of annexin II and V expression, terminal differentiation, mineralization and apoptosis in human osteoarthritic cartilage. Osteoarthritis Cartilage 2000, 8:294-302.

3. Aigner T, Reichenberger $\mathrm{E}$, Bertling W, Kirsch T, Stoss H, von der MK: Type X collagen expression in osteoarthritic and rheumatoid articular cartilage. Virchows Arch B Cell Pathol Incl Mol Pathol 1993, 63:205-211.

4. Li T, Xiao J, Wu Z, Qiu G: Over-expression of c-maf by chondrocytes in osteoarthritis. J Int Med Res 2009, 37:129-135.

5. Wang X, Manner PA, Horner A, Shum L, Tuan RS, Nuckolls GH: Regulation of MMP-13 expression by RUNX2 and FGF2 in osteoarthritic cartilage. Osteoarthritis Cartilage 2004, 12:963-973.

6. Reboul P, Pelletier JP, Tardif G, Cloutier JM, Martel-Pelletier J: The new collagenase, collagenase-3, is expressed and synthesized by human chondrocytes but not by synoviocytes. A role in osteoarthritis. J Clin Invest 1996, 97:2011-2019.

7. Inada M, Wang Y, Byrne MH, Rahman MU, Miyaura C, Lopez-Otin C, Krane SM: Critical roles for collagenase-3 (Mmp13) in development of growth plate cartilage and in endochondral ossification. Proc Natl Acad Sci U S A 2004 101:17192-17197.

8. Stickens D, Behonick DJ, Ortega N, Heyer B, Hartenstein B, Yu Y, Fosang AJ, Schorpp-Kistner M, Angel P, Werb Z: Altered endochondral bone development in matrix metalloproteinase 13-deficient mice. Development 2004, 131:5883-5895.

9. Fraser A, Fearon U, Billinghurst RC, lonescu M, Reece R, Barwick T, Emery $\mathrm{P}$, Poole AR, Veale DJ: Turnover of type II collagen and aggrecan in cartilage matrix at the onset of inflammatory arthritis in humans: relationship to mediators of systemic and local inflammation. Arthritis Rheum 2003, 48:3085-3095.

10. Poole AR, Rizkalla G, lonescu M, Reiner A, Brooks E, Rorabeck C, Bourne R, Bogoch E: Osteoarthritis in the human knee: a dynamic process of cartilage matrix degradation, synthesis and reorganization. Agents Actions Supp/ 1993, 39:3-13.

11. Hermansson M, Sawaji Y, Bolton M, Alexander S, Wallace A, Begum S, Wait R, Saklatvala J: Proteomic analysis of articular cartilage shows increased type Il collagen synthesis in osteoarthritis and expression of inhibin betaA (activin A), a regulatory molecule for chondrocytes. J Biol Chem 2004, 279:43514-43521.

12. Aigner T, Zien A, Gehrsitz A, Gebhard PM, McKenna L: Anabolic and catabolic gene expression pattern analysis in normal versus osteoarthritic cartilage using complementary DNA-array technology. Arthritis Rheum 2001, 44:2777-2789.

13. Martel-Pelletier J, McCollum R, DiBattista J, Faure MP, Chin JA, Fournier S, Sarfati M, Pelletier JP: The interleukin-1 receptor in normal and osteoarthritic human articular chondrocytes. Identification as the type I receptor and analysis of binding kinetics and biologic function. Arthritis Rheum 1992, 35:530-540.

14. Shlopov BV, Gumanovskaya ML, Hasty KA: Autocrine regulation of collagenase 3 (matrix metalloproteinase 13) during osteoarthritis. Arthritis Rheum 2000, 43:195-205.

15. Dingle JT: Catabolin - a cartilage catabolic factor from synovium. Clin Orthop Relat Res 1981, 156:219-231.

16. Martel-Pelletier J: Pathophysiology of osteoarthritis. Osteoarthritis Cartilage 2004, 12(Suppl A):S31-S33.

17. Vuolteenaho K, Moilanen T, Jalonen U, Lahti A, Nieminen $R$, van Beuningen $H$ M, van der Kraan PM, Moilanen E. TGF $\beta$ inhibits IL-1-induced iNOS expression and NO production in immortalized chondrocytes. Inflamm Res 2005, 54:420-427.

18. Pasternak RD, Hubbs SJ, Caccese RG, Marks RL, Conaty JM, DiPasquale G: Interleukin-1 stimulates the secretion of proteoglycan- and collagendegrading proteases by rabbit articular chondrocytes. Clin Immunol Immunopathol 1986, 41:351-367

19. Takahashi N, Rieneck K, van der Kraan PM, van Beuningen HM, Vitters EL,

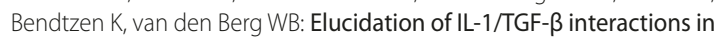
mouse chondrocyte cell line by genome-wide gene expression. Osteoarthritis Cartilage 2005, 13:426-438.

20. Bocquet J, Daireaux M, Langris M, Jouis V, Pujol JP, Beliard R, Loyau G: Effect of a interleukin-1 like factor (mononuclear cell factor) on proteoglycan synthesis in cultured human articular chondrocytes. Biochem Biophys Res Commun 1986, 134:539-549.

21. Goldring MB, Birkhead JR, Suen LF, Yamin R, Mizuno S, Glowacki J, Arbiser JL, Apperley JF. Interleukin-1 beta-modulated gene expression in immortalized human chondrocytes. J Clin Invest 1994, 94:2307-2316.

22. Bhatnagar R, Penfornis H, Mauviel A, Loyau G, Saklatvala J, Pujol JP Interleukin-1 inhibits the synthesis of collagen by fibroblasts. Biochem Int 1986, 13:709-720.

23. Redini F, Galera P, Mauviel A, Loyau G, Pujol JP: Transforming growth factor beta stimulates collagen and glycosaminoglycan biosynthesis in cultured rabbit articular chondrocytes. FEBS Lett 1988, 234:172-176.

24. Redini F, Daireaux M, Mauviel A, Galera P, Loyau G, Pujol JP: Characterization of proteoglycans synthesized by rabbit articular chondrocytes in response to transforming growth factor-beta (TGF- $\beta$ ). Biochim Biophys Acta 1991, 1093:196-206.

25. Goldring MB: The role of cytokines as inflammatory mediators in osteoarthritis: lessons from animal models. Connect Tissue Res 1999, 40:1-11.

26. van der Kraan PM, Glansbeek HL, Vitters EL, van den Berg WB: Early elevation of transforming growth factor-beta, decorin, and biglycan mRNA levels during cartilage matrix restoration after mild proteoglycan depletion. J Rheumatol 1997, 24:543-549.

27. Govinden R, Bhoola KD: Genealogy, expression, and cellular function of transforming growth factor-beta. Pharmacol Ther 2003, 98:257-265.

28. Lawrence DA: Latent-TGF- $\beta$ : an overview. Mol Cell Biochem 2001, 219:163-170.

29. Konig HG, Kogel D, Rami A, Prehn JH: TGF $\beta$, activates two distinct type I receptors in neurons: implications for neuronal NF-KB signaling. J Cell Biol 2005, 168:1077-1086

30. Finnson KW, Parker WL, ten DP, Thorikay M, Philip A: ALK1 opposes ALK5/ Smad3 signaling and expression of extracellular matrix components in human chondrocytes. J Bone Miner Res 2008, 23:896-906.

31. Goumans MJ, Valdimarsdottir G, Itoh S, Lebrin F, Larsson J, Mummery C, Karlsson S, ten Dijke P: Activin receptor-like kinase (ALK)1 is an antagonistic mediator of lateral TGFbeta/ALK5 signaling. Mol Cell 2003, 12:817-828.

32. Wu X, Ma J, Han JD, Wang N, Chen YG: Distinct regulation of gene expression in human endothelial cells by TGF- $\beta$ and its receptors. Microvasc Res 2006, 71:12-19.

33. Seki T, Hong KH, Oh SP: Nonoverlapping expression patterns of ALK1 and ALK5 reveal distinct roles of each receptor in vascular development. Lab Invest 2006, 86:116-129.

34. Goumans MJ, Valdimarsdottir G, Itoh S, Rosendahl A, Sideras P, ten Dijke P: Balancing the activation state of the endothelium via two distinct TGF-beta type I receptors. EMBO J 2002, 21:1743-1753.

35. Zhang YE: Non-Smad pathways in TGF-ßsignaling. Cell Res 2009, 19:128-139.

36. Sorrentino A, Thakur N, Grimsby S, Marcusson A, von B, V, Schuster N, Zhang S, Heldin CH, Landstrom M: The type I TGF- $\beta$ receptor engages TRAF6 to activate TAK1 in a receptor kinase-independent manner. Nat Cell Biol 2008 10:1199-1207. 
37. Kamiya M, Harada A, Mizuno M, Iwata H, Yamada Y: Association between a polymorphism of the transforming growth factor- $\beta$, gene and genetic susceptibility to ossification of the posterior longitudinal ligament in Japanese patients. Spine 2001, 26:1264-1266.

38. Yamada Y, Okuizumi H, Miyauchi A, Takagi Y, Ikeda K, Harada A: Association of transforming growth factor beta 1 genotype with spinal osteophytosis in Japanese women. Arthritis Rheum 2000, 43:452-460.

39. Kizawa H, Kou I, lida A, Sudo A, Miyamoto Y, Fukuda A, Mabuchi A, Kotani A, Kawakami A, Yamamoto S, Uchida A, Nakamura K, Notoya K, Nakamura Y, Ikegawa S: An aspartic acid repeat polymorphism in asporin inhibits chondrogenesis and increases susceptibility to osteoarthritis. Nat Genet 2005, 37:138-144

40. Rodriguez-Lopez J, Pombo-Suarez M, Liz M, Gomez-Reino JJ, Gonzalez A: Lack of association of a variable number of aspartic acid residues in the asporin gene with osteoarthritis susceptibility: case-control studies in Spanish Caucasians. Arthritis Res Ther 2006, 8:R55.

41. Jiang Q, Shi D, Yi L, Ikegawa S, Wang Y, Nakamura T, Qiao D, Liu C, Dai J: Replication of the association of the aspartic acid repeat polymorphism in the asporin gene with knee-osteoarthritis susceptibility in Han Chinese. J Hum Genet 2006, 51:1068-1072.

42. Serra R, Johnson M, Filvaroff EH, Laborde J, Sheehan DM, Derynck R, Moses $\mathrm{HL}$ : Expression of a truncated, kinase defective TGF-beta type II receptor in mouse skeletal tissue promotes terminal chondrocyte differentiation and osteoarthritis. J Cell Biol 1997, 139:541-552.

43. Yang X, Chen L, Xu XL, Li CL, Huang CF, Deng CX: TGF- $\beta /$ Smad3 signals repress chondrocyte hypertrophic differentiation and are required for maintaining articular cartilage. J Cell Biol 2001, 153:35-46.

44. Dabovic B, Chen Y, Colarossi C, Zambuto L, Obata H, Rifkin DB: Bone defects in latent TGF- $\beta$ binding protein (Ltbp)-3 null mice, a role for Ltbp in TGFßpresentation. J Endocrinol 2002, 175:129-141.

45. Vivien D, Galera P, Loyau G, Pujol JP: Differential response of cultured rabbit articular chondrocytes (RAC) to transforming growth factor beta (TGF- $\beta$ ) - evidence for a role of serum factors. Eur J Cell Biol 1991, 54:217-223.

46. Vivien D, Galera P, Lebrun E, Daireaux M, Loyau G, Pujol JP: TGF- $\beta$-induced G2/M delay in proliferating rabbit articular chondrocytes is associated with an enhancement of replication rate and a cAMP decrease: possible involvement of pertussis toxin-sensitive pathway. J Cell Physio/ 1992, 150:291-298.

47. Vivien D, Redini F, Galera P, Lebrun E, Loyau G, Pujol JP: Rabbit articular chondrocytes (RAC) express distinct transforming growth factor-beta receptor phenotypes as a function of cell cycle phases. Exp Cell Res 1993, 205:165-170.

48. Pujol JP, Galera P, Pronost S, Boumediene K, Vivien D, Macro M, Min W, Redini F, Penfornis H, Daireaux M: Transforming growth factor-beta (TGF- $\beta$ ) and articular chondrocytes. Ann Endocrinol (Paris) 1994, 55:109-120.

49. Boumediene K, Felisaz N, Pujol JP: Cell-cycle-dependent expression of transforming growth factor beta type I receptor correlates with differential proliferative effects of TGF $\beta$ in articular chondrocytes. Exp Cell Res 1998, 243:173-184.

50. Pujol JP, Chadjichristos C, Legendre F, Bauge C, Beauchef G, Andriamanalijaona R, Galera P, Boumediene K: Interleukin-1 and transforming growth factor-beta 1 as crucial factors in osteoarthritic cartilage metabolism. Connect Tissue Res 2008, 49:293-297.

51. Legendre F, Dudhia J, Pujol JP, Bogdanowicz P: JAK/STAT but not ERK1/ERK2 pathway mediates interleukin (IL)-6/soluble IL-6R down-regulation of type II collagen, aggrecan core, and link protein transcription in articular chondrocytes. Association with a down-regulation of SOX9 expression. J Biol Chem 2003, 278:2903-2912.

52. Blaney Davidson EN, Scharstuhl A, Vitters EL, van der Kraan PM, van den Berg WB: Reduced transforming growth factor-beta signaling in cartilage of old mice: role in impaired repair capacity. Arthritis Res Ther 2005, 7:R1338-R1347.

53. Scharstuhl $A$, van Beuningen HM, Vitters EL, van der Kraan PM, van den Berg WB: Loss of transforming growth factor counteraction on interleukin 1 mediated effects in cartilage of old mice. Ann Rheum Dis 2002, 61:1095-1098.

54. Galera P, Redini F, Vivien D, Bonaventure J, Penfornis H, Loyau G, Pujol JP: Effect of transforming growth factor-beta 1 (TGF- $\beta$ 1) on matrix synthesis by monolayer cultures of rabbit articular chondrocytes during the dedifferentiation process. Exp Cell Res 1992, 200:379-392.

55. van der Kraan PM, Vitters E, van den BW: Differential effect of transforming growth factor beta on freshly isolated and cultured articular chondrocytes. J Rheumatol 1992, 19:140-145

56. Morales TI: Transforming growth factor-beta 1 stimulates synthesis of proteoglycan aggregates in calf articular cartilage organ cultures. Arch Biochem Biophys 1991, 286:99-106.

57. Morales TI, Roberts AB: Transforming growth factor beta regulates the metabolism of proteoglycans in bovine cartilage organ cultures. $J$ BiOl Chem 1988, 263:12828-12831.

58. van Beuningen HM, van der Kraan PM, Arntz OJ, van den Berg WB: Transforming growth factor-beta 1 stimulates articular chondrocyte proteoglycan synthesis and induces osteophyte formation in the murine knee joint. Lab Invest 1994, 71:279-290.

59. Blaney Davidson EN, Scharstuhl A, Vitters EL, van der Kraan PM, van den Berg WB: Reduced transforming growth factor-beta signaling in cartilage of old mice: role in impaired repair capacity. Arthritis Res Ther 2005, 7:R1338-R1347

60. Livne $E$, Laufer D, Blumenfeld I: Differential response of articular cartilage from young growing and mature old mice to IL-1 and TGF- $\beta$. Arch Gerontol Geriatr 1997, 24:211-221.

61. McCaffrey TA, Falcone DJ: Evidence for an age-related dysfunction in the antiproliferative response to transforming growth factor-beta in vascular smooth muscle cells. Mol Bio/ Cell 1993, 4:315-322.

62. Mailhot G, Yang M, Mason-Savas A, Mackay CA, Leav I, Odgren PR: BMP-5 expression increases during chondrocyte differentiation in vivo and in vitro and promotes proliferation and cartilage matrix synthesis in primary chondrocyte cultures. J Cell Physio/ 2008, 214:56-64.

63. Li X, Schwarz EM, Zuscik MJ, Rosier RN, lonescu AM, Puzas JE, Drissi H, Sheu TJ, O'keefe RJ: Retinoic acid stimulates chondrocyte differentiation and enhances bone morphogenetic protein effects through induction of Smad1 and Smad5. Endocrinology 2003, 144:2514-2523.

64. Nishihara A, Fujii M, Sampath TK, Miyazono K, Reddi AH: Bone morphogenetic protein signaling in articular chondrocyte differentiation. Biochem Biophys Res Commun 2003, 301:617-622.

65. Bau B, Haag J, Schmid E, Kaiser M, Gebhard PM, Aigner T: Bone morphogenetic protein-mediating receptor-associated Smads as well as common Smad are expressed in human articular chondrocytes but not up-regulated or down-regulated in osteoarthritic cartilage. J Bone Miner Res 2002, 17:2141-2150

66. Drissi MH, Li X, Sheu TJ, Zuscik MJ, Schwarz EM, Puzas JE, Rosier RN, O'keefe $\mathrm{RJ}$ : Runx2/Cbfa1 stimulation by retinoic acid is potentiated by BMP2 signaling through interaction with Smad1 on the collagen $\mathrm{X}$ promoter in chondrocytes. J Cell Biochem 2003, 90:1287-1298.

67. Li X, lonescu AM, Schwarz EM, Zhang X, Drissi H, Puzas JE, Rosier RN, Zuscik MJ, O'keefe RJ: Smad6 is induced by BMP-2 and modulates chondrocyte differentiation. J Orthop Res 2003, 21:908-913.

68. Horiki M, Imamura T, Okamoto M, Hayashi M, Murai J, Myoui A, Ochi T, Miyazono K, Yoshikawa H, Tsumaki N: Smad6/Smurf1 overexpression in cartilage delays chondrocyte hypertrophy and causes dwarfism with osteopenia. J Cell Bio/ 2004, 165:433-445

69. Zuscik MJ, Baden JF, Wu Q, Sheu TJ, Schwarz EM, Drissi H, O'keefe RJ, Puzas JE, Rosier RN: 5-Azacytidine alters TGF- $\beta$ and BMP signaling and induces maturation in articular chondrocytes. J Cell Biochem 2004, 92:316-331.

70. LiTF, Darowish M, Zuscik MJ, Chen D, Schwarz EM, Rosier RN, Drissi H, O'Keefe $\mathrm{RJ}$ : Smad3-deficient chondrocytes have enhanced BMP signaling and accelerated differentiation. J Bone Miner Res 2006, 21:4-16.

71. Yang $X$, Chen $L, X u X$, Li C, Huang C, Deng CX: TGF- $\beta$ /Smad3 signals repress chondrocyte hypertrophic differentiation and are required for maintaining articular cartilage. J Cell Biol 2001, 153:35-46.

72. Ferguson CM, Schwarz EM, Reynolds PR, Puzas JE, Rosier RN, O'keefe RJ: Smad2 and 3 mediate transforming growth factor-beta1-induced inhibition of chondrocyte maturation. Endocrinology 2000, 141:4728-4735.

73. Zhou S, Eid K, Glowacki J: Cooperation between TGF- $\beta$ and Wnt pathways during chondrocyte and adipocyte differentiation of human marrow stromal cells. J Bone Miner Res 2004, 19:463-470.

74. Zhu M, Tang D, Wu Q, Hao S, Chen M, Xie C, Rosier RN, O'Keefe RJ, Zuscik M, Chen D: Activation of $\beta$-catenin signaling in articular chondrocytes leads to osteoarthritis-like phenotype in adult beta-catenin conditional activation mice. J Bone Miner Res 2009, 24:12-21.

75. Zhu M, Chen M, Zuscik M, Wu Q, Wang YJ, Rosier RN, O'Keefe RJ, Chen D: Inhibition of $\beta$-catenin signaling in articular chondrocytes results in articular cartilage destruction. Arthritis Rheum 2008, 58:2053-2064.

76. Weng LH, Wang CJ, Ko JY, Sun YC, Su YS, Wang FS: Inflammation induction of Dickkopf-1 mediates chondrocyte apoptosis in osteoarthritic joint. 
Osteoarthritis Cartilage 2009, 17:919-929

77. Fuentealba LC, Eivers E, Ikeda A, Hurtado C, Kuroda H, Pera EM, De Robertis EM: Integrating patterning signals: Wnt/GSK3 regulates the duration of the BMP/Smad1 signal. Cell 2007, 131:980-993.

78. Furumatsu T, Ozaki T, Asahara H: Smad3 activates the Sox9-dependent transcription on chromatin. Int J Biochem Cell Biol 2009, 41:1198-1204.

79. Mackay AM, Beck SC, Murphy JM, Barry FP, Chichester CO, Pittenger MF: Chondrogenic differentiation of cultured human mesenchymal stem cells from marrow. Tissue Eng 1998, 4:415-428.

80. Hecht J, Seitz V, Urban M, Wagner F, Robinson PN, Stiege A, Dieterich C, Kornak U, Wilkening U, Brieske N, Zwingman C, Kidess A, Stricker S, Mundlos $S$ : Detection of novel skeletogenesis target genes by comprehensive analysis of a Runx2-- mouse model. Gene Expr Patterns 2007, 7:102-112

81. Javed A, Bae JS, Afzal F, Gutierrez S, Pratap J, Zaidi SK, Lou Y, van Wijnen AJ Stein JL, Stein GS, Lian JB: Structural coupling of Smad and Runx2 for execution of the BMP2 osteogenic signal. J Biol Chem 2008, 283:8412-8422.

82. Leboy P, Grasso-Knight G, D'Angelo M, Volk SW, Lian JV, Drissi H, Stein GS, Adams SL: Smad-Runx interactions during chondrocyte maturation. J Bone Joint Surg Am 2001, 83A(Suppl 1):S15-S22.

83. Hjelmeland AB, Schilling SH, Guo X, Quarles D, Wang XF: Loss of Smad3mediated negative regulation of Runx2 activity leads to an alteration in cell fate determination. Mol Cell Biol 2005, 25:9460-9468.

84. Blaney Davidson EN, Vitters EL, van der Kraan PM, van den Berg WB. Expression of transforming growth factor-beta (TGF $\beta$ ) and the TGF $\beta$ signalling molecule SMAD-2P in spontaneous and instability-induced osteoarthritis: role in cartilage degradation, chondrogenesis and osteophyte formation. Ann Rheum Dis 2006, 65:1414-1421.

85. Blaney Davidson EN, Remst DF, Vitters EL, van Beuningen $\mathrm{HM}$, Blom AB, Goumans MJ, van den Berg WB, van der Kraan PM: Increase in ALK1/ALK5 ratio as a cause for elevated MMP-13 expression in osteoarthritis in humans and mice. J Immunol 2009, 182:7937-7945.

86. Finnson KW, Parker WL, ten DP, Thorikay M, Philip A: ALK1 opposes ALK5/ Smad3 signaling and expression of extracellular matrix components in human chondrocytes. J Bone Miner Res 2008, 23:896-906.

87. van Beuningen $H M$, Glansbeek $H L$, van der Kraan PM, van den Berg WB: Differential effects of local application of BMP-2 or TGF- $\beta 1$ on both articular cartilage composition and osteophyte formation. Osteoarthritis Cartilage 1998, 6:306-317

88. Glansbeek HL, van Beuningen HM, Vitters EL, van der Kraan PM, van den Berg WB: Stimulation of articular cartilage repair in established arthritis by local administration of transforming growth factor-beta into murine knee joints. Lab Invest 1998, 78:133-142.

89. van Beuningen HM, van der Kraan PM, Arntz OJ, van den Berg WB: In vivo protection against interleukin-1-induced articular cartilage damage by transforming growth factor-beta 1: age-related differences. Ann Rheum Dis 1994, 53:593-600

90. van Beuningen HM, van der Kraan PM, Arntz OJ, van den Berg WB: Protection from interleukin 1 induced destruction of articular cartilage by transforming growth factor beta: studies in anatomically intact cartilage in vitro and in vivo. Ann Rheum Dis 1993, 52:185-191.
91. van Beuningen HM, Glansbeek HL, van der Kraan PM, van den Berg WB: Osteoarthritis-like changes in the murine knee joint resulting from intraarticular transforming growth factor-beta injections. Osteoarthritis Cartilage 2000, 8:25-33.

92. Scharstuhl $A$, van Beuningen HM, Vitters EL, van der Kraan PM, van den Berg WB: Loss of transforming growth factor counteraction on interleukin 1 mediated effects in cartilage of old mice. Ann Rheum Dis 2002, 61:1095-1098

93. Blaney Davidson EN, Scharstuhl A, Vitters EL, van der Kraan PM, van den Berd WB: Reduced transforming growth factor-beta signaling in cartilage of old mice: role in impaired repair capacity. Arthritis Res Ther 2005, 7:R1338-R1347.

94. Tesseur I, Zou K, Esposito L, Bard F, Berber E, Can JV, Lin AH, Crews L, Tremblay $P$, Mathews P, Mucke L, Masliah E, Wyss-Coray T: Deficiency in neuronal TGF- $\beta$ signaling promotes neurodegeneration and Alzheimer's pathology. J Clin Invest 2006, 116:3060-3069.

95. Das P, Golde T: Dysfunction of TGF- $\beta$ signaling in Alzheimer's disease. J Clin Invest 2006, 116:2855-2857.

96. Zhang H, Zou K, Tesseur I, Wyss-Coray T: Small molecule TGF- $\beta$ mimetics as potential neuroprotective factors. Curr Alzheimer Res 2005, 2:183-186.

97. Glaser KB, Li J Aakre ME, Morgan DW, Sheppard G, Stewart KD, Pollock J, Lee P, O'Connor CZ, Anderson SN, Mussatto DJ, Wegner CW, Moses HL: Transforming growth factor beta mimetics: discovery of 7-[4-(4-cyanophenyl)phenoxy]-heptanohydroxamic acid, a biaryl hydroxamate inhibitor of histone deacetylase. Mol Cancer Ther 2002, 1:759-768

98. Bernard DJ, Lee KB, Santos MM: Activin B can signal through both ALK4 and ALK7 in gonadotrope cells. Reprod Biol Endocrinol 2006, 13:52.

99. Fernandez L, Sanz-Rodriguez F, Blanco FJ, Bernabeu C, Botella LM: Hereditary hemorrhagic telangiectasia, a vascular dysplasia affecting the TGF- $\beta$ signaling pathway. Clin Med Res 2006, 4:66-78.

100. Li X, lonescu AM, Schwarz EM, Zhang X, Drissi H, Puzas JE, Rosier RN, Zuscik MJ, O'Keefe RJ: Smad6 is induced by BMP-2 and modulates chondrocyte differentiation. J Orthop Res 2003, 21:908-913.

101. Iwai T, Murai J, Yoshikawa H, Tsumaki N: Smad7 inhibits chondrocyte differentiation at multiple steps during endochondral bone formation and down-regulates p38 MAPK pathways. J Biol Chem 2008, 283:27154-27164.

102. Fuentealba LC, Eivers E, Ikeda A, Hurtado C, Kuroda H, Pera EM, De Robertis EM. Integrating patterning signals: Wnt/GSK3 regulates the duration of the BMP/Smad1 signal. Cell 2007, 131:980-993.

103. Inoue $Y$, Imamura T. Regulation of TGF- $\beta$ family signaling by E3 ubiquitin ligases. Cancer Sci 2008, 99:2107-2112.

doi:10.1186/ar2896

Cite this article as: ven der Kraan PM, et al:: A role for age-related changes in TGF $\beta$ signaling in aberrant chondrocyte differentiation and osteoarthritis. Arthritis Research \& Therapy 2010, 12:201. 